\title{
Internal Control of Accounting Information System based on Network Environment
}

\author{
Biao Liü, a \\ ${ }^{1}$ Jiangxi Science \& Technology Normal University, Finance Department, Nanchang, Jiangxi, \\ 330013 \\ ${ }^{a}$ email
}

Keywords: Network Environment, Accounting Information, Internal Control System Research

\begin{abstract}
With the development and progress of modern computer networks, internal accounting information systems in a network environment with a corresponding change of control. Accounting Information System under the network environment is a more complex data processing system for the analysis and processing accounting data information. Internal accounting information system This paper will control the network environment for analysis and research.
\end{abstract}

\section{Introduction}

In the network environment, accounting information system is different from the traditional manual accounting and computerized accounting, in a networked environment, with some changes, reflected in the internal control, and many other means. Network environment accounting information system in the collection, transport, storage of data will be exposed some problems, we need a way to improve internal controls, accounting information system has been improved to promote better able to play a role in the operation of the enterprise, as business operators to provide sufficient reference information to facilitate the economic activities of enterprises.

\section{Internal Control of Accounting Information System}

Internal control of accounting information systems refers to the relevant rules and regulations of enterprises and institutions in order to ensure the integrity of the normal business activities of accounting, accounting data, and the accuracy of corporate assets, in accordance with the accounting principles and accounting system, developed, control, business processes, etc. related management measures [1]. Internal accounting control system, need to rely on the computer's internal controls, internal controls and accounting organization of internal control manual interaction of the three, in order to achieve internal control of accounting information system, so that the accounting data processing activities can have enough scientific and accurate and security. Internal control is an important basis for accounting information system can work properly, it is possible for information systems play an effective supporting role, outwardly, to achieve effective control action from the inside, so that the accounting information system to achieve normal and stable operation, so that the accounting data You can have accuracy. Internal accounting control systems and enterprise business needs and workflows combined with evolving accounting information system and make the appropriate adjustments to ensure that the process can give full play to the role of accounting data.

Internal control activities are divided into general accounting system control and application controls two categories. It is the general control of the main elements of the entire accounting information system is controlled so that elements of the entire accounting information system enables stable operation that factors related to the role can be realized. General controls can establish the overall structure of the accounting information system, it is possible to control the relevant elements be supported, providing control support. Application controls is to establish specific control refers to the process of accounting information systems, primarily on the basis of the control of the general control, to achieve specific business data analysis and processing. Application of control embodied in specific resistance and application characteristics, controls the 
activity of the specific accounting accounting elements and specific business data processing.

\section{Internal Control Changes of Accounting Information System under Network}

In the network environment, the system of internal accounting controls on the control will have a greater change in control of the content and scope of control has also adjusted accordingly. Accounting control system in the form of internal control changes, mainly in the network environment, some of the internal accounting controls of traditional information processing is no longer important, these internal controls are easy to write a computer program in a network environment, the programmed computer software substituted [2]. Internal accounting control system network environment having a manual control and system control features are combined with manual control and system control. In addition, the internal control environment, the traditional manual accounting information system will be integrated into a computer program.

In the network environment, computer networks and computer software will be widely used, it can lead to internal control content changes. Network Environment accounting no longer need to duplicate work for processing accounting data, the more dependent on the help of computer technology, primarily for accounting personnel that will make accurate accounting data input, the stability of the computer running of certain control measures adopted. Internal accounting control system network environment will result in a reduction of accounting personnel, enabling processing efficiency of accounting information to enhance processing accuracy of the data is guaranteed. In the traditional manual accounting information processing, it is necessary to rely on each other to contain the accounting staff to achieve the accuracy and fairness of accounting data processing in the network environment, accounting and internal control systems by virtue of computer data and computer software impartial operation and computer algorithms to achieve accuracy of the data, to avoid the traditional accounting systems to contain personnel may result in internal accounting risks occur. Internal accounting control system network environment, to avoid the traditional accounting systems possible problems, optimize the operation of accounting information systems.

Some control internal accounting system under network environment control, will be simplified or be internalized into the computerized accounting information systems, specific control measures will be omitted [3]. Internal accounting system under the control of the network environment, these features can be found accounting errors that occur in a short time, so that the quality of accounting data processing increases, to avoid accounting errors and no longer be solved within a short time caused by the cumulative loss. Finally, internal accounting control system under the network environment, it is possible to make the accounting between the various departments sharing and transfer of accounting data, so that the accounting departments are able to achieve accounting and review data calls, get rid of the existence of certain risks before accountants contain.

Internal accounting control system network environment occurred a greater degree of change reflected in the flow of business processes within the enterprise and accounting data accounting information, and many other changes in the flow of business processes and accounting information, accounting data, will make the accounting information processing system of internal departments and personnel, timely access to relevant accounting information, so that business activities can be obtained in a timely transfer of various departments, the departments became operations center accounting activities. To a certain extent, the internal accounting control system network environment has been more in the range significantly expanded, which also led to the occurrence of the accounting system control points corresponding adjustments to the internal accounting control system network environment more difficult.

\section{Promotion of Internal Control to Accounting Information Systems under Network Environment}

In the traditional manual accounting information processing, to a certain extent, it is difficult to avoid the occurrence of distortion of accounting information, although with multiple accounting oversight, and internal check of accounting, but still difficult to effectively prevent such problems 
from occurring. Internal accounting system under network environment control, can set a good enterprise culture, were established relevant audit supervision department, it is possible to improve the relevant accounting supervision and management system to realize the accounting data processing supervision and management, accounting information truthfulness and accuracy, can be effectively protected. In accountancy, internal accounting control system capable of managing the agency and to some extent led to solve problems, to avoid accounting problems caused by asymmetric information, so that the accounting manager's behavior can be effectively related constraints, to avoid adverse events happened. Accounting internal control system network environment, it is possible in terms of security information to protect their own business interests and investors, so that the accounting activities to achieve certain Chengdu transparent, prevent managers adverse selection and similar accounting irregularities occur behavior.

Accounting information system is an important part of corporate accounting activities, supporting the enterprise's economic and business activities for business operators to provide the adequate accounting information to facilitate decision-making operators [4]. Real-time accounting information system also reflects the enterprise's economic operating conditions for businesses to achieve their own supervision and management, in a timely manner to solve the problem. Accounting information system security is to ensure that the premise of business activities, but also enables enterprises to get important support development and progress. In the internal accounting control system network environment, through a series of accounting control measures to ensure the security of accounting information systems. Internal accounting control system, will ensure the security of the accounting information system as work content, to ensure that the accounting information system to achieve a stable and secure operation of use, so that the accounting information to be between the enterprise and between enterprises to achieve smooth transfer and safe to use.

\section{Conclusion}

Network Accounting Information System has some changes, which, through the improvement and improve internal controls to achieve the purpose of the use of information systems security. In the future development of the accounting information system, the need to pay attention to adjust and improve internal control, so that enterprises can achieve more standardized accounting activities.

\section{References}

[1] Yan Xiaoqin .ERP internal accounting information system control environment [J]. contemporary economic, 2012,06: 72-73.

[2] Xia Tangbin. Guard against the risk of internal accounting information system under network environment based control [J]. Chinese securities and futures, 2012,07: 146-147.

[3] Tang Shuangni. The internal.ERP environmental accounting information system [J]. control financial and economic, 2012, 24: 200-201.

[4] Zhu Yini. control network environment impact analysis [J]. internal accounting information system Chifeng University (Natural Science), 2011, 09: 67-69. 